\title{
Hiato: A Pause in Darkness to Reflect the Future*
}

\author{
Maryllu de Oliveira Caixeta \\ University of São Paulo, São Paulo, Brasil
}

\begin{abstract}
This article deals with the short story "Hiato", part of the collection Tutaméia: Terceiras estórias by João Guimarães Rosa. When Tutaméia was released, it caused some discomfort for being too inventive. We will analyze the story in relation to the book proposal and the literary field when it was released. The short story presents an allegory of deform or an indetermination procedure that creates deformations in the form. "Hiato" is related to the author's concept of fiction as a representation that validates itself through the relations it establishes with cultural representations. These relations of representation with culture call attention to the significances that history aggregates to linguistic uses and, simultaneously, proposes meaninglessness of decisive representational moments. The effect is a critical reflection on the historicity of representations in culture which fiction makes undetermined as a future strategy.
\end{abstract}

Keywords: João Guimarães Rosa, Tutaméia, Hiato, allegory, indetermination

\section{Introduction}

In life, João Guimarães Rosa achieved success among both the public and critics. He was especially successful with his only novel Grande sertão: veredas, translated into English as The devil to pay in the backlands. The author's work has also been adapted several times into theater and cinema. During his lifetime, he saw his publications translated into French, Italian, German, English, and Spanish. Apart from the novel, four short-story anthologies were published during his life. The last one was Tutaméia: Terceiras estórias, in 1967. The author died a year later, three days after becoming a member of the Academia Brasileira de Letras (Brazilian Academy of Letters).

Although it was the last book to be published, Rosa had pondered over Tutaméia since 1937, while editing the manuscripts of Sagarana, which would be released only in 1946 (Sperber, 1982, p.103). Therefore, the project and even the writing of Tutaméia may have followed the author for several years. Some of the 44 texts of the books were individually published in journals before 1967. It is curious that the author had taken such a long time to publish Tutaméia, and the silence that followed reinforced the hypothesis that he knew it would be a provocative book. In a conversation with Paulo Rónai, Rosa referred to Tutaméia as a "true obstacle course" for the reader (Rosa, 1979, p.194).

In this article, we study the obstacle proposed in the short story "Hiato", which proposes an allegory of form deformation or a "total deform" portrayed as a frightening bull that appears in the way of the cowboys. The noun "hiatus" (hiato) defines a cut, a discontinuity, and a gap. The use of the verb deform as a noun can be seen as a neologism composed by the noun form and the prefix de- which indicates denial, separation, and

\footnotetext{
* Acknowledgements: The research is supported by Fundação de Amparo à Pesquisa do Estado de São Paulo (FAPESP). Maryllu de Oliveira Caixeta, postdoutoral’s researcher, University of São Paulo.
} 
privation. The allegory has a double meaning: It refers to the literal appearance of the bull and means the complete deform that subtracts from the form. The cuts or hiatus in the form emanates its significant reach, and simultaneously, denies the natural substance of the form, affirming it as a rhetorical technique.

\section{Hiato: An allegory ${ }^{1}$}

I can appropriate myself of a certain signification by constructing it according to my intention thanks to the opacity of the sign that I connect to the object. When enunciating an allegory, I use the sign opacity to multiply its meaning; I use the image of something sensitive or of a fable to suggest an idea. As an allegory uses the sign's bilateral unity, it serves to naturalize the platonic notion that the sensitive world is a mimesis of the idea. In the period we normally call "baroque", there was a constant notion that sensitive forms represented in names make a mimesis of superior and ineffable meanings. Plato domesticated the mimesis by putting it under the philosopher's domain and Aristoteles established the criteria of verisimilitude to justify only the poetry that corresponded to the internal logic considered necessary by the philosopher. Since then, mimesis creation has been under the philosopher's judgement, which was able to differentiate true and acceptable models of simulacra and paralogisms.

Tutaméia proposes allegories that simultaneously refer to and distort rhetorics circumscribed to acceptable models as mimesis of a superior truth. Each anecdote repeats the suggestion of a superior meaning mimicked in the form that has, as an "internal logic", the non-sense, the fame, or the deformation of mimesis models and realistic representation patterns. According to Hansen (2000, p.123), Rosa imitates, parodies, and ironizes style itself in Tutaméia. He uses allegories in the fiction of what is indescribable that enacts imaginary effects as if they corresponded to a significance of significations.

As an allegory, it proposes a fable that would correspond to a superior meaning. It is at the same time realistic and metaphysical. The state of things narrated is a mimesis of an idea, a logical model, and a thought system. In the preface of Tutaméia entitled "Aletria e hermêutica”, the author proposes the pattern of the stories in the book. It is composed by anecdotes that use poetic techniques to produce transcendence. The techniques used in these anecdotes are subtraction operations that deform or empty the form: knives without handles or blades; balloons without "skin". Each short story aims at a transcendental effect and, simultaneously, supports the fictional character in the superior meaning it holds. The semantic deformation is owned to the fact that the superior meaning is fictional and illusional, instead of substantial, as in the platonic allegories.

Rosa's literature almost always narrates situations in the backlands. The geographical backlands and their representation in a literate culture provide the social and linguistic material that the author uses to compose the allegories. As the backlands are a marginalized region, in a certain way unknown, their references are adequate to allegories. The referent is distant and mysterious. The author formulates allegories of a metaphysical backland, creating it in the gaps of historiography. He allegorizes the backland suggesting "superior" meaning fiction that, ironically, creates realistic effects as it deals with realities unknown by a literate culture.

The recurrent reference to the backlands motivated Rosa's first critical reception to compare him to regional literature, classified as such because it referred to inland parts of the country, outside the big urban centers. Apart from the common interest in the country's inland, there are fundamental differences between Rosa and regionalist authors. Since his first book, Sagarana, Candido (2000) pointed out the difference of Rosa, which can be

${ }^{1}$ Translated from Portuguese by Viviane Coelho Caldeira Ramos and by Elize Miyuki Kawauchi. 
received with interest by readers around the world, by the reach or ontological signification of his fictional work.

In an interview published in the magazine Arquipélago, Candido mentioned some traces of regionalism and their modifications through the decades. In the Brazilian context, regional literature started in the romantic 19th century. The first newspapers helped to fill the incipient urban-reader public with a fantasy and vainglorious literature about regions that are difficult to access. The country was going through a process that would lead to the independence from Portugal, in 1822. The Republic, started in 1889, nourished a certain middle-class expansion in the cities. In this context, regionalism acquired a satirical axis that typifies the speech and the culture of rural characters contrasting them with a literate narrator. From 1930, northeast regionalism abandoned this satirical tendency and moved closer to a colloquial register both in the characters' speech as well as the narrator's (Fischer, 2005).

Regional literature normally adopts a realistic convention, registering social issues of different cultures that live in this continental country. As the country's colonization started by the coast, where urban centers started to develop, the so-called regional literature includes different authors and matters present in the more hegemonic systems. What we call backlands is also a generality. It covers vast extensions in the countryside, with different geographies and cultures. The many regions and cultures of the backlands have in common the fact that in a way they are excluded from official history and stigmatized in literate culture. We normally refer to the backland using interpretative schemes that encompass loitering, violence, work relations, and punctual historical events. These are used as keys to a nation's critical reading so as to propose adapted solutions from imported models. According to Hansen (2000, p.192), Brazilian intellectual imagery on interpretative nets to "surround the backland of flowers or barbed wire", Brasilian intellectuals usually praise country culture or report its incivility. Rosa used this exclusion of the geographical backlands from the official history and the illusional imagery that maintains the interest of a literate culture in the backland. Rosa invented a backland fiction in these empty spaces, using it as a source for allegories such as the one in "Hiato".

The critics normally align the author with the modernist movement of São Paulo (1922 to 1929). The modernists valued aesthetic research, humor, and parody. In these aspects the alignment is justified. On the other hand, there are relevant differences. Modernists shared a project of aesthetic update of Brazilian literature. To do so, they sometimes used colloquialisms and celebrated the contribution of native thinking over a rationalism attributed to the colonizer, aiming for the appreciation of national interests.

In Rosa's case, inventiveness is not regulated by these postulates. Rosa uses language in a much more inventive way making it the fiction of a speech that motivates the relation between signifier and significance. Rosa explores the significant potential of language in the fiction of a speech similar to the one spoken before Babel (Hansen, 2007). The critic to rationalism, that creates universal interest, is made through non-sensical procedures. It combines backland social matters to parodies in regional texts as well as world-wide ones, including philosophy, religion, botany, literature, mythology, esotericism, etc..

\section{The Hiatus: A Pause for Reflection That Makes the Future Undetermined}

Tutaméia is an inventive book. Each of its forty stories has two or three pages. There are four prefaces among the stories. These prefaces do not have the expected explanatory function, as they are enigmatic, anecdotal, and only the last is narrated in the first person. The book's configuration is also peculiar and detailed. A very meaningful detail for the style interpretation is the reading index in the beginning and, later again, at the end of the book with some modifications. The index's repetition already suggests that the reading is not over. 
Each index has as an epigraph-a quotation by Schopenhauer that promises some kind of enlightening if the reader is patient enough for a second reading and connects the parts to the "organic" whole. The author is ironic when subscribing to the metaphor of the organic work in the book's epigraph that proposes allegories in fictions that communicate the device's validity and deforms the substantiality of the rhetoric they refer to. The story "Hiato" allegorizes deformations in the form and concludes, reversing Platonism, which fiction enlightens the sensitive world defined by implied decision in the boldness of representation.

In the book's index, the titles of the stories and forewords are listed in alphabetic order from A, "Aletria e hermenêutica" to Z, "Zingaresca". The title's alphabetical order is interrupted at the letter "G" that only reappears to form the order of the author's initials JGR. The stories are "João Porém, o criador de perus", "Grande Gedeão", and "Reminisção". In the hiatus of the alphabetical order and the stories in the JGR order, there is a story that thematizes the empty spaces, making decisive points undetermined in the representation. The title itself "Hiato" refers to a reflexive pause that follows the indetermination effect.

The first preface of Tutaméia, "Aletria e hermenêutica”, defines story as a way of being that denies history. This denial neither means the author's lack of interest in the story nor a deliberation to fantasy, nor a baroque point of view on the illusory nature of history. The story puts history in question when combining determination and indetermination in the mimesis of available cultural representation, starting with linguistic uses. The author defines the story as a being that wants to be fiction, which does not want to be seen as a realist scheme of reading history that represented a determinate and exclusive point of view.

According to the Tutaméia's foreword, the fictional instrumentalizes the poetic technique in order to reach the effects of poetic transcendence. The inventiveness of these subtraction techniques is proportional to the grandness or the representation patterns they deflate. The historical discursive practices constitute the motivated appearance of significance that, as they circulate, appears determined. When poetry subtracts or refuses the common uses of signs, it dislocates the significances and shows that they are decisions we take when connecting the signs. The most inventive technique, because it is mostly subtracting, is the "myth mechanism" (Rosa, 1979, p.5). The current space determinations are studied by hard sciences (physics, chemistry, biology, geography, etc.) and time determinations are studied by sciences that interpret historical processes (psychology, history, sociology, economy, anthropology, etc.). Mythical narratives reduce to a minimum or even suspend the determinations of time-space to consecrate a reality principle or an ontological sense. The mythical narratives largely use the indetermination to communicate an essential meaning to anyone interested in conceiving the denial of a limit, in transcending a determination.

Rosa's literature uses indetermination to intervene with philological attention in the historical uses of language and the rhetoric implied in them. The story "Hiato" points out a criterion to the use of indetermination: It reports to a future meaning. It is a strategy of myth indetermination that sacralizes existing realities in a distant or past place, with nostalgic effects. If in the myths the indeterminations sacralize the meaning of a primordial reality, in the short-story the empty spaces open for each non-sense linguistic use require a pause for inconclusive reflection that gets even more complicated in a second reading. The lack of fencing in the bushes gathers the cowboys in the poetry, a free play, and makes an indetermination regulated only by the consciousness of the danger implied on deciding or acting.

\section{The Biggest Bull or the Total Deform}

Tutaméia opts for a non-sense that dismantles or subtracts the classical notion of plot. In the short stories 
of Tutaméia, each ending narrates an unusual overcome of the initial limit situation or its meaning. This overcoming is supported by non-sense operations incorporated in the linguistic uses of every story and mainly in the transcendental turn that ends the anecdote. The reader, accustomed to finding an internal logic to the plot, receives the ending as a challenge or a puzzle. In a second reading, he starts to establish connections of incompatible orders. Then, the indetermination effects dislocate the significance of the first reading that followed the anecdote "line" before the ending completely shudders it. In the story "Hiato", a frightening bull figures the indetermination that creates deformations in the form. After the confrontation with the bull, the cowboys go up hill. In the distance that seems to paralyze the vague or indeterminate contours of a superior meaning, the remembrance of the recent danger highlights the limitations or determines the cowboys in relation to the bull:"escuro como o futuro, mau objeto para a memória” (dark as the future, bad object to memory) (Rosa, 1979, p.62).

The allegory narrates the cowboys' journey and the climax is the bull's sudden appearance that qualifies a total deform. The communicative function is assured by the grammar of the syntaxes and the clarity of this small anecdote: the journey, the meeting with the bull, and the climbing of the hill where the cowboys rest.

The fiction of the story's unity parodies and deforms the enactment of one day in the tragic poetry that the Poetics follow as a model. In the backlands, the intrepid journey starts in the morning and ends in the solace of the night. The confrontation with the bull's character, in both senses of the term, is decisive and mandatory, as the three cowboys see themselves between the bull and a narrow road on the edge of an abyss. They had to pass one at a time. The first is the young and hesitant Põe-põe encouraged by the old man Nhácio, in the rearguard, who claims that courage needs to be practiced. The dangerous situation shows the judgment or the implied decision in the representation. The cowboys go up hill and leave the river behind. The river symbolizes the changes of beings. When the characters move away from the river, they start a pause for reflection on recent events. The anti-platonic inference of the narrator and the rest or pause ensued by the sunset ending. The narrator reflects on the reaction of Nhácio to the recent confrontation with the bull and takes it from a lesson that deforms the platonic hierarch of the shadows' world that receives an illusional light, inside the sun of reason.

"De onde vem então o medo? Ou este terráqueo mundo é de trevas, o que resta do sol tentando iludir-nos do contrário" (So, where does fear come from? Or this terrestrial world is made of darkness, the remains of the sun attempting to deceive us otherwise) (Rosa, 1979, p. 63).

In a first reading, this lesson reiterates the respect to the oral culture of Nhácio that serves as a matter that the author appropriates in the creation of the allegory that we interpret later, in a second reading.

\section{The Narrator, Põe-põe and Nhácio}

The allegory uses some decisive neologisms to the meaning of representation as a deformation of the form (desforma), vocabulary presented in dictionaries, and backlands' social matters related to the Native-Brazilian Põe-põe and the cafuzo ${ }^{2}$ Nhácio. The choosing of these topics, which deal with very determined assumptions, avoids the common places of violence, technological precariousness, and caricatured speech. The violence and lack of State is cushioned in the allegory that fills poetry with the very descriptive narrative of the journey. The violence and confrontation with nature's dangers are themes treated lightly, almost at the end of the story.

2 The term cafuzo refers to people who have both Native-Brazilian and African origins. 
There is only a quick mention of the murder of the Native's father, with no further explanations. The encounter with the bull almost sums up the anecdote and, even so, fills only a paragraph of the story. In Tutaméia, the situations of violence and danger span just a few lines in each story even though they are decisive in creating the limit situations reverted by the endings. The story mentions violence in lawless spaces and the main dangers in fenceless pasture, but the allegory differs greatly from the common places of regional literature.

Rosa is known for the inventive use of the language, even though there is predominance in his texts of widespread vocabulary and the "telegraphic syntaxes" which do not interfere in the communication value (Daniel, 1968). Urban readers are now a majority in Brazil. The lexicon may present some difficulties, even if they relate to regional and Brazilian aspects. In the short period of Rosa's production, Brazil passed from a rural country to an urban one. The speediness of the modernization process has also created a cultural hiatus between parents and children. A type of literature such as Rosa's, which deals with areas outside hegemonic urban centers, also invents a memory for this rural Brazil that has "deflated" in a period of few decades. Vocabulary difficulties do not prevent "Hiato" readers to understand the anecdote or the fable, already in a first reading. The strategic use of neologism and unknown vocabulary, regional or not, enriches a second reading of the allegory. In a first reading one can interpret it as a realistic story that values the oral knowledge of the Native-Brazilian and the cafuzo. A second reading can broaden the meaning of the fable and perceive it as an allegory through which the author proposes points of view over what is fictional.

The allegory has three characters. The first is the narrator that merely observes his participation in the journey only in a meaningful detail. When the bull appears, the narrator says that he and the other cowboys felt the fear of the horses from underneath their thighs, and this made the horses snore like a sleeping man. Sometimes in Tutaméia, not only in "Hiato", the author compares men to cattle. The cowboys that drive the cattle are self-employed professionals as most writers. Considering the position of the story "Hiato" in the book's title index, the story is part of a group that deals with authorship. The author serves as a parody channel, as an open ear that proposes pauses to reflect on the representations that circulate around the world. The other two cowboys are the cafuzo Nhácio and the indigenous Põe-põe.

At the end of the story, Nhácio complains of old age and says he cannot drive the cattle any longer. The young man Põe-põe, a relative, disagrees, showing his loyalty and recognition of the old man's stature. The cafuzo and the native are from a multiracial lineage. In it, ethnicity transforms itself and both socio-cultural specificities to get other meanings. In the allegory, miscegenation is the meaning's changing constitution. The name Nhácio seems to imitate the pronunciation of the name Inácio by part of Brazilian ancestors from Cape Verde and Guinea-Bissau. Possibly, the strong Jesuit presence in the beginning of Brazilian colonization popularized the name of Saint Ignatius of Loyola. Until today, it is a very popular name in Brazil. Two interesting examples are:Ignácio da Catingueira, who was a slave and troubadour born at the end of the 19th century. Another is the naïf painter Ignácio da Nega, Rosa’s contemporary. The surname "Nega” serves as a loving reference to the painter's black mother that named him after the black pope.

The first General of the Society of Jesus was Ignatius of Loyola, also known as the black pope because of his black garment which distinguished him from the pope's white garment. He lived in the period known as the baroque and developed some meditation techniques that develop mental faculties through imagination and empathy. The Spiritual exercises guide the practitioner's imagination to visualize events as those narrated in the Gospel, hell, the battle between good and bad, passion, Christ's death and glory, etc.. They use image techniques, tropes, and verbal games intending to activate the imagination and understanding of those who 
meditate. Loyola taught meditation as a way of ordering life as it removes from the soul disordered emotions to prepare it to receive the divine light (Loyola, 2000).

In the texts, fine arts, public ceremonies in the baroque period, motifs of grief and death, macabre scenes, subjects of illusion, fiction, and dream were frequent. The taste for allegories expressed a worldview that each death was the last meaning of an illusional history. The grieving atmosphere related to the nature they considered muted and blurred by sin. "The writing itself, which represents the speech that rewrites nature and history becomes vain, struck by the plenitude of divine absolute science, always beyond” (Hansen, 2006, p. 205). A mixed or transfiguring lineage connects Nhácio to Põe-põe. Each part of the Native's double name takes an accent that sounds playful and refers to the verb "pôr", which means put, narrate, dislocate, figure, and dispose. Doubled and with no playful accent, we are left with the name Poe, which seems to refer to Edgar Allan Poe, the master of short stories.

In a critical essay on Hawthorne, Poe (1973) made some concessions to allegories that coincide with his idea of fiction. Fiction should reveal a double reality for the reader. Through the apparent meaning of the narrative, there should be the suggestion of a hidden meaning that surprises the reader when the end of the text gives unity to the effect. Poe considers this effect unity as fiction's most vital point and it is allegory that does it. On the other hand, Poe complains about traditional allegory as it sacrifices seriousness and verisimilitude. Poe's aversion to traditional allegories is due to the fact that they relate to insubstantial concepts and ideals. The traditional allegory is a bridge or a metaphysical justification to a certain state of things. In contrast, Poe proposes that an allegory should be used in the destruction of fictions naturalized by common sense. An allegory can be an act that demystifies fictions shared by a culture as if they were substantial truths. It can be a fact if the author uses it as a tool to shatter another allegory, a fiction, or a common sense. When destroying the surface illusions, the allegory opens space to the reader's volition, which happens when the reader relates their experience to the allegory's suggestive effect. Poe believes that the allegory should be used to destroy forced identifications of signs and things. He saw the world as a space of illusions that veils sinister realities.

\section{Conclusion}

The story "Hiato" refers to the allegory concepts of Loyola and Poe. It dislocates the platonic notion that a substantial reality would contain the truth that the world hides. Departing from the dualist notion of reality, Rosa's story withholds the evaluation that considers the sensible world lower than the metaphysical matter as well as deceiving regarding the functioning of the historic world. It affirms the form as a deformation of usual practice of rhetorical form and the allegory's fictional character that, even so, is valid as a tool of indetermination of current representations. According to this idea, the space opened by the deformation of the form creates consciousness and makes room for a different future.

\section{References}

Candido, A. (2000). A educação pela noite e outros ensaios (Education by night and other essays). São Paulo: Ática.

Daniel, M. L. (1968). Guimarães Rosa: Travessia literária (Guimarães Rosa: Literary travelling). Rio de Janeiro: José Olympio.

Ficher, L. (2005). Antonio Candido: Um olhar decisivo sobre o Brasil (Antonio Candido: A decisive look to Brasil). Arquipélago: Revista de Livros e Ideias, 28-34.

Hansen, J. A. (2000).O “O”. A fiç̧ão da literatura em Grande sertão: veredas (The “The”. Literature’s fiction in the devil to pay in the backlands). São Paulo: Hedra.

Hansen, J. (2007). Grande sertão: Veredase o ponto de vista avaliativo do autor (The devil to pay in the backlands and the author's point of view). Nonada, 10(1), 57-75. Retrieved May 30, 2009, from 
http://seer.uniritter.edu.br/index.php/nonada/article/view/39/13

Loyola, I. (2000). Exercícios espirituais (Spiritual exercises). São Paulo: Edições Loyola.

Poe, E. (1973). Nathaniel Hawthorne. In Ensayos y Críticas (Esays and Criticism) (pp. 125-141). Madrid: Alianza.

Rosa, J. G. (1979). Tutaméia: Terceiras estórias (Trifle: The third stories). Rio de Janeiro: José Olympio.

Sperber, S. F. (1982). Tutaméia (Trifle). In Signo e Sentimento (Sign and feeling) (pp.103-110). São Paulo: Ática. 